https://dx.doi.org/10.4314/iijikm.v10i1.6

Information Impact:

Journal of Information and Knowledge Management

Vol. 10 (1), June, 2019

ISSN: 2141-4297 (Print) ISSN: 2360-994X (Online)

\title{
Users' Satisfaction with Information Resources in Libraries of Agricultural Research Institutes in Nigeria
}

\author{
Razika Mohammed Yahaya \\ University Library, Bayero University Kano-Nigeria \\ E-mail: razyahaya@yahoo.com
}

\begin{abstract}
The paper examined the level of users' satisfaction with information resources in libraries of Agricultural research institutes in Nigeria. The objectives were to: to identify information resources in libraries of agricultural research institutes; to find out the level of users' satisfaction with the information resources and to find out the challenges face by users. Quantitative research method using cross sectional survey research design was used. The data collection instrument for the study was questionnaire. Population for this study comprised the nineteen (19) National Agricultural Research Institutes in Nigeria, with 2,325 Research Scientists (users) from which sample was drawn. Simple random sampling technique was used to select Six (6) libraries. Sample size for the study is 946 users (researchers). The major findings were that the users were satisfied with relevancy, content and accuracy of information resources. While on the other hand the users were not satisfied with organization of information resources, accessibility to print and electronic resources, and means of awareness. The study recommended among others that the libraries studied should provide improved power supply by using solar energy and or inverters, up-to-date print and e-resources regularly, and create awareness to their availability in the library.
\end{abstract}

\section{Keywords: Agricultural Research institutes, Information resources, Satisfaction, Users} Nigeria.

\section{Introduction}

Naturally information resources get to the end users through a number of intermediaries, but sometimes it gets to the end users directly. The intermediates are of two categories: The first one is information infrastructural institutions which include libraries, archives, records offices, records management institutions, publishing organizations and museums, while the second is information professionals trained to make the information available to end user (Aina, 
2004). Research institutes play a very important role in agricultural development of any nation. The mandates for the establishment of the institutes form the basis for the existence of the library as well as its operation. Their libraries provide the necessary academic materials and information resources needed for training and coordinating researches carried out in the institutes, which the nation needs for the engineering of social, economic, industrial, agricultural and technological development. Ntui and Orim (2014) maintained that a good library should be well equipped with books and periodicals in all subjects to advance study and research. The essence of any facility in a library is to satisfy the provision of relevant information

\section{Objectives:}

1. To identify the types of information resources used in agricultural research institutes libraries under study;

\section{Review of Related Literature}

In the library, users are considered to be at the focal point, meaning that resources and services needed by its user. Library will not serve its purpose if resources and services provided by the library do not satisfy user's need. High level of service quality leads to higher levels of customer's satisfaction (Naeem and Saif, 2009). The user of the library is more like a customer, the library has to provide or keep in stock relevant information resources to cater for the need of their users. Doing so effectively and efficiently will lead to satisfaction of the user. The study was interested in knowing the level of users' satisfaction with the information resources and services in the libraries of agricultural research institutes in Nigeria because the libraries exist to satisfy their user's information needs.

2. To find out the level of user's satisfaction with the information resources;

3. To find out the challenges faced by users in the libraries under study

whatever activities carried out should be done with the user in mind because they are the costumers in the library. User's 
satisfaction is about the customer's overall evaluation of the performance of an offering. In the agricultural research institutes of Nigeria the up-to-datedness and good quality of scientific research environment depend on how effective the library is in identifying and connecting information resources on current developments in various subject fields with the researchers.

The collection must also be accessible to the users. The provision of quality information resources will invariably have positive impact on the research environment; on the contrary, if the quality of the information resources provided leaves much to be desired, the result would be worse, and this will be more noticeable in the nature of research carried out by the research scientists.

A study was carried out by Chavez et al. (2005) on a survey of the students, faculty and staff to measure their satisfaction with the Paradise Valley Community College Library. The study revealed that users were satisfied with the resources, facilities and circulation service. Recommendation was given to repeat survey in two years to compare satisfaction level of the respondents again. In another study carried out by Koovakki and Jalaja (2005) titled Satisfaction of the Carrier Seekers in the Resources and Services of Libraries in Kerala. It was ascertained that the level of satisfaction of career seekers in the resources and services of university, college and public libraries, revealed that users using university libraries were most satisfied and using public libraries were least satisfied. A difference was also observed between the level of satisfaction of male and female users. In the same vein Liu and Allmang (2008) conducted a survey titled Assessing Customer Satisfaction at the NIST Research Library: 
The study revealed that journals continued to be the most valuable resource for NIST scientists, with overwhelming preferences for e-journals.

Similarly, in a study titled Information System Effectiveness: A User's Satisfaction Approach Study of Francis Sulemanu (F. S.) Idachaba Library University of Agriculture Makurdi, Benue State, Nigeria conducted by Uganneya and Idachaba (2005), to ascertain the level of effectiveness of F.S. Idabacha Library by the students and teachers of University of Agriculture Makurdi, Circulation and Information Technology services were deficient. Frequency of use of library was low, which indicates that library did not meet information needs of users properly. Respondents suggested the introduction of new journals and the Internet service to improve the library system.

Satisfaction of library users is a function of the quality of information product(s) received, the quality of information system and library services provided to access the information products. Iwhiwhu and Okorodudu (2012) the satisfaction of library users is a function of the quality of information product(s), received, the quality of information system and library services provided to access the information products. The information resources will focus on whether the library's resources are relevant, adequate and current as well as the format meeting user needs and expectations; the library facilities will focus on functionality and adequacy of facilities in research library; and the service quality will be looked at from the perceptions of users about resources/services offered including library staff competency. Therefore, in the libraries of agricultural research libraries, satisfaction is a function of three main sources, quality of the information 
product, the information system and the services that makes the information product available to the users.

These three levels of measure of satisfaction are defined by the information resources, facilities and services. The modern concept of library is user oriented which makes user the focus of all activities. If expectations are fulfilled the users are satisfied and if the library does not meet the expectations, the users are not satisfied. It is natural that only satisfied users come back and there are greater chances that dissatisfied user will ultimately find some other source of information resources to meet their information needs (Owusu-Acheaw and Larson 2012). Without a functional library, qualitative research activities in the agricultural research institutes are impossible. Library users are satisfied when the library is able to achieve this, so the users should be at the focal point of the library (Ntui and Orim 2014).

Information resources that are provided by the library to users but not well utilized or not utilized at all cannot lead to satisfaction or happiness. This cannot, therefore in any way lead to human advancement, talk less of agricultural development. Hence, one of the basic objectives of information resources is that it must be relevant to the user's needs at any given time before it will be well utilized. Agricultural research institutes are special libraries, thus, their services may differ from services of other libraries because of the nature of their users and their information needs. 


\section{Methodology}

The study used quantitative research method and a cross-sectional survey design the total population for this study comprised the nineteen (19) National Agricultural Research Institutes in Nigeria, with 2,325 Research Scientists (users) from which sample was drawn. Simple random sampling technique was used to select Six (6) libraries. Sample size for the study was 946 users

\section{RESULT AND DISCUSSION}

\section{Types of information resources used}

(researchers). Hence, in choosing the sample the researcher used the mandates of the institutes establishment as criteria for grouping to allow for easy selection, therefore, one institute was chosen from each sub-group. The instrument used for the collection of data was a questionnaire. Descriptive statistics in frequencies and percentage were obtained using the Statistical Package for Social Sciences (SPSS) version 22 for Windows7. 


\begin{tabular}{|c|c|c|c|c|c|c|c|c|c|c|c|c|}
\hline Institutes & & Books & Mag & Jour & Gaz. & $\begin{array}{l}\text { Govt. } \\
\text { pub }\end{array}$ & Map & Dict. & Ency. & Pamphlet & N/paper & Con.proc \\
\hline \multirow[t]{2}{*}{ LCRI } & Yes & 30 & 30 & 30 & 29 & 29 & 30 & 30 & 30 & 30 & 30 & 30 \\
\hline & No & 0 & 0 & 0 & 1 & 1 & 0 & 0 & 0 & 0 & 0 & 0 \\
\hline \multicolumn{2}{|l|}{ Total } & 30 & 30 & 30 & 30 & 30 & 30 & 30 & 30 & 30 & 30 & 30 \\
\hline \multirow[t]{2}{*}{ NAERLS } & Yes & 109 & 92 & 106 & 37 & - & 78 & 58 & 77 & 65 & 55 & 102 \\
\hline & No & 16 & 33 & 19 & 88 & - & 47 & 67 & 48 & 60 & 70 & 23 \\
\hline \multicolumn{2}{|l|}{ Total } & 125 & 125 & 125 & 125 & - & 125 & 125 & 125 & 125 & 125 & 125 \\
\hline \multirow[t]{2}{*}{ NISPRI } & Yes & 47 & 42 & 46 & 17 & 17 & 31 & 19 & 36 & 33 & 36 & 39 \\
\hline & No & 0 & 5 & 1 & 30 & 30 & 16 & 28 & 11 & 14 & 11 & 8 \\
\hline \multicolumn{2}{|l|}{ Total } & 47 & 47 & 47 & 47 & 47 & 47 & 47 & 47 & 47 & 47 & 47 \\
\hline \multirow[t]{2}{*}{ FRIN } & Yes & 148 & 135 & 148 & 109 & 109 & 124 & 112 & 139 & 124 & 119 & 135 \\
\hline & No & 3 & 16 & 3 & 42 & 42 & 27 & 39 & 12 & 27 & 32 & 16 \\
\hline \multicolumn{2}{|l|}{ Total } & 151 & 151 & 151 & 151 & 151 & 151 & 151 & 151 & 151 & 151 & 151 \\
\hline \multirow[t]{2}{*}{ NIOMR } & Yes & 169 & 149 & 158 & 76 & 76 & 123 & 122 & 120 & 126 & 117 & 148 \\
\hline & No & 10 & 30 & 21 & 103 & 103 & 56 & 57 & 59 & 53 & 62 & 31 \\
\hline \multicolumn{2}{|l|}{ Total } & 179 & 179 & 179 & 179 & 179 & 179 & 179 & 179 & 179 & 179 & 179 \\
\hline \multirow[t]{2}{*}{ NAPRI } & Yes & 83 & 61 & 63 & 27 & 27 & 58 & 61 & 58 & 39 & 43 & 68 \\
\hline & No & 4 & 26 & 24 & 60 & 60 & 29 & 26 & 29 & 48 & 44 & 19 \\
\hline \multicolumn{2}{|l|}{ Total } & 87 & 87 & 87 & 87 & 87 & 87 & 87 & 87 & 87 & 87 & 87 \\
\hline
\end{tabular}

This part of the paper provides answer to the first objective which aimed at identifying types of information resources used in the libraries studied. Result of the study revealed that the users of libraries studied use both print and electronic resources. In relation to print information resources used in the libraries. Respondents were asked to indicate the type of print information resources they use in their respective libraries. The finding of the study revealed print information resources used include Books, magazines, Journal, Gazette, Government publications in form of (circular memos), Maps, Dictionaries, Encyclopedia, Pamphlets (as extension materials), newspapers, conference proceeding. In LCRI respondents indicated the use of these print information resources majority of the users $(93.3 \%)$ indicate usage while $(6.7 \%)$ indicated lack of use of two of these information resources, Government 
Publications and Gazette, this may be attributed to the lack of relevance to their research work. In NAERLS, the use of print information resources in the library was indicated by $(70 \%)$ usage for most these print information resources expect government publications by researches and other users while (30\%) of respondents indicated less usage of these information resources.

In NSPRI more than half of the users $(60 \%)$ use most of the information resources while (40\%) indicated less use. FRIN less than half $(47 \%)$ indicate the use of most of these print information resources while $(53 \%)$ indicated less usage of most of these resources. At NIOMR more than half $(70 \%)$ respondents indicated the use of these print information resources while (30\%) of the respondents indicated less use of most of these information resources. In NAPRI majority $(80 \%)$ of respondents indicate the use of print information resources while (20\%) does not use most of these information resources.

The use of print information resources by users in the various research institutes confirm the view of Choo (2002), who view information use as a dynamic interactive social process in inquiry that may result in making a meaning to decision making. Wilson, (2003) affirmed that information generation in essence is to build up information resources that will cater for users need. It follows therefore, that print information resources in the studied libraries were used based on the relevant information needs of the user. Libraries in research institutes being special in nature, value information resources and this help to enhance the users performance in carrying out day to day activities as Oyewusi and Oyebode (2009) described information resource to users and depend on what information is 
generated and became relevant to their

activities.

\section{Use of e-resources}

\begin{tabular}{|c|c|c|c|c|c|c|c|c|c|c|c|c|c|c|c|c|}
\hline $\begin{array}{l}\text { Name of } \\
\text { institutes }\end{array}$ & & $\begin{array}{l}\text { Fil } \\
\text { ms }\end{array}$ & $\begin{array}{l}\text { Slid } \\
\text { es }\end{array}$ & CD & $\begin{array}{l}\text { Rec } \\
\text { ord }\end{array}$ & e-b & e- j & e-z & $\begin{array}{l}\text { Int. } \\
\text { Res. }\end{array}$ & $\begin{array}{l}\text { AGO } \\
\text { RA }\end{array}$ & $\begin{array}{l}\text { TEE } \\
\text { AL }\end{array}$ & $\begin{array}{l}\text { EBS } \\
\text { C. }\end{array}$ & $\begin{array}{l}\text { HINAR } \\
\text { Y }\end{array}$ & $\begin{array}{l}\text { ELSE } \\
.\end{array}$ & AGRIS & $\begin{array}{l}\text { AGRI } \\
\text { COL } \\
\text { A }\end{array}$ \\
\hline \multirow[t]{2}{*}{ LCRI } & Yes & - & - & - & - & - & 13 & 6 & 18 & 8 & - & - & - & - & - & - \\
\hline & No & - & - & - & - & - & 17 & 24 & 12 & 22 & - & - & - & - & - & - \\
\hline Total & & - & - & - & - & - & 30 & 30 & 30 & 30 & - & - & - & - & - & - \\
\hline \multirow{2}{*}{ NAERLS } & Yes & - & - & - & 71 & 64 & 59 & - & 94 & 46 & 52 & - & - & 12 & - & - \\
\hline & No & - & - & - & 54 & 61 & 66 & - & 31 & 79 & 73 & - & - & 113 & - & - \\
\hline Total & & - & - & - & 125 & 125 & 125 & - & 125 & 125 & 125 & - & - & 125 & - & - \\
\hline \multirow[t]{2}{*}{ NISPRI } & Yes & - & - & - & - & 22 & 18 & 12 & 23 & 37 & 34 & 3 & 6 & 7 & 7 & - \\
\hline & No & - & - & - & - & 25 & 29 & 35 & 24 & 10 & 13 & 44 & 41 & 40 & 40 & - \\
\hline Total & & - & - & - & - & 47 & 47 & 47 & 47 & 47 & 47 & 47 & 47 & 47 & 47 & - \\
\hline \multirow[t]{2}{*}{ FRIN } & Yes & 65 & 67 & 81 & 75 & 65 & 60 & - & 95 & 78 & 70 & 8 & 49 & 19 & 19 & 16 \\
\hline & No & 86 & 84 & 70 & 76 & 86 & 91 & - & 56 & 73 & 81 & 143 & 102 & 132 & 132 & 135 \\
\hline Total & & 151 & 151 & 151 & 151 & 151 & 151 & - & 151 & 151 & 151 & 151 & 151 & 151 & 151 & 151 \\
\hline \multirow{2}{*}{ NIOMR } & Yes & - & - & 36 & 46 & 124 & 115 & 81 & 96 & 48 & 115 & - & 95 & 32 & 13 & - \\
\hline & No & - & - & 143 & 133 & 55 & 64 & 98 & 83 & 131 & 64 & - & 84 & 147 & 166 & - \\
\hline Total & & - & - & 179 & 179 & 179 & 179 & 179 & 179 & 179 & 179 & - & 179 & 179 & 179 & - \\
\hline \multirow[t]{2}{*}{ NAPRI } & Yes & 40 & - & 46 & 40 & 26 & - & - & 40 & 26 & 16 & - & 12 & 9 & 9 & 14 \\
\hline & No & 47 & - & 41 & 47 & 61 & - & - & 47 & 61 & 71 & - & 75 & 78 & 78 & 73 \\
\hline \multicolumn{2}{|c|}{ Total Respondents } & 87 & - & 87 & 87 & 87 & - & - & 87 & 87 & 87 & - & 87 & 87 & 87 & 87 \\
\hline
\end{tabular}


The finding of this paper revealed eresources in the studied libraries to include Film, Slides, CD, Record, e-Book, eJournal, e-Magazine, Internet Resources, AGORA, TEEAL, EBSCOHOST, HINARY, AGRIS, AGRICOLA and Elsevier being used by researchers in the various libraries. However, availability depends on different Institute library. In LCRI majority of the respondent indicated that they do not use e-resources. In NAERLS most of the respondent indicated the use of e-resources. In NISPRI more than half of the respondent indicated use of eresources in the library. In FRIN majority of the users indicated non use of e-resources. In NIOMR more than half of the respondents indicated use of some of the e-resources. In NAPRI most of the respondents indicated that they do not use e-resources despite the fact that the library have the collection but there are some factors preventing the use. The factors on non-use of some of the e- resources found in libraries of agricultural research institutes is similar to the finding of Owolabi, Idowu, Okocha and Ogundare (2016) in their paper on the utilization of electronic information resources by the undergraduate students of university of Ibadan investigated the factors that hindered the use of electronic information resources by the students. Among the factors, inadequate power supply was a major problem, which had the highest ranking (156 or $83 \%$ ) of response rates. Following this is the poor network/internet connectivity (148 or $78.7 \%$ ) and limited access to computer terminals (112 or $59.6 \%)$ as well as too much information retrieved (107 or $56.9 \%$ ). Their study result has shown that the use of electronic information resources by the undergraduate students is a bit low. Inadequate power supply and the inadequate provision of key electronic resources and facilities in the library were identified as the key factors militating against the effective 
use of the electronic information resources.

These were among the factors that are also

\begin{tabular}{|l|l|l|l|l|l|l|l|l|}
\hline \multicolumn{2}{|l|}{ Satisfaction } \\
\hline \multirow{2}{*}{ Institutes } & Relevancy & Content & Format & Quality & Organization & $\begin{array}{l}\text { Access to } \\
\text { e-resources }\end{array}$ & $\begin{array}{l}\text { Access } \\
\text { to Print } \\
\text { resources }\end{array}$ & $\begin{array}{l}\text { Means of } \\
\text { awareness }\end{array}$ \\
\hline \multirow{3}{*}{ LCRI } & 3.02 & 3.00 & 3.00 & 3.00 & 1.07 & 1.07 & 3.00 & 3.00 \\
\cline { 2 - 9 } & Satisfied & Satisfied & Satisfied & Satisfied & Unsatisfied & Unsatisfied & Satisfied & Satisfied \\
\hline \multirow{3}{*}{ NAERLS } & 2.95 & 2.81 & 3.07 & 3.14 & 3.02 & 2.84 & 2.89 & 2.83 \\
\cline { 2 - 9 } & Satisfied & Satisfied & Satisfied & Satisfied & Satisfied & Satisfied & Satisfied & Satisfied \\
\hline \multirow{3}{*}{ NISPRI } & 2.68 & 2.62 & 2.55 & 2.38 & 2.49 & 2.17 & 2.57 & 2.30 \\
\cline { 2 - 9 } & Satisfied & Satisfied & Satisfied & Unsatisfied & Unsatisfied & Unsatisfied & Satisfied & Unsatisfied \\
\hline \multirow{3}{*}{ NIOMR } & 3.05 & 2.88 & 2.81 & 2.55 & 2.72 & 2.49 & 2.94 & 2.62 \\
\cline { 2 - 9 } & Satisfied & Satisfied & Satisfied & Satisfied & Satisfied & Unsatisfied & Satisfied & Satisfied \\
\cline { 2 - 9 } NAPRI & Satisfied & Satisfied & Satisfied & Satisfied & Satisfied & Satisfied & Satisfied & Satisfied \\
\cline { 2 - 9 } & Satisfied & Satisfied & Satisfied & Satisfied & Satisfied & Satisfied & Satisfied & Satisfied \\
\hline
\end{tabular}

found in the libraries studied.

\section{Satisfaction on use of information resources}

Looking at the Table above it can be clearly seen that the respondent in all of the institutes studied indicated that they are satisfied with the Relevancy, Content, Format, Quality, Access to print resources and Means of awareness. As for organization of information resources respondents from LCRI and NISPRI indicated that they are not satisfied. So also for Access to e-resources respondents from LCRI, NISPRI and FRIN indicated that they are not satisfied. Libraries of agricultural research institutes are special libraries and exist to satisfy their users. Their satisfaction is a function of the quality of the information product(s) received and the quality of information system and library services provided to access the information products.

The findings of this study is in line with that of Iwhiwhu and Okorodudu (2012) that the satisfaction of library users is a function of 
the quality of the information product(s) received and the quality of information system and library services provided to access the information products. The information resources will focus on whether the library's resources are relevant, adequate and current as well as the format meeting user needs and expectations; the library facilities will focus on functionality and adequacy of the facilities in research library; and the service quality will be looked at from the perceptions of users about resources/services offered, including library staff competency. Likewise, in the libraries of agricultural research libraries, satisfaction is a function of three main sources, quality of the information product, the information system and the services that make the information product available to users. It is natural that only satisfied users comes back and there are greater chances that dissatisfied user will ultimately find some other source of information resources to meet their information needs (OwusuAcheaw \& Larson 2012).

The result displayed implies that the libraries studied match information resources with the need of the users through relevancy, content, format, quality, access to print resources and means of awareness. As for organization of information resources respondents from LCRI and NISPRI indicated that they are not satisfied. So also for access to eresources respondents from LCRI, NISPRI and FRIN indicated that they are not satisfied. This might not be out of the fact that the libraries studied do not use modern trend of organization.

\section{Challenges}

\begin{tabular}{|l|l|l|l|l|l|l|}
\hline Challenges & LCRI & NAERLS & NISPRI & FRIN & NIOMR & NAPRI \\
\hline $\begin{array}{l}\text { Inadequate Information } \\
\text { Resources }\end{array}$ & 11 & 25 & 26 & 81 & 51 & 30 \\
\hline Poor library services & 9 & 36 & 16 & 67 & 76 & 28 \\
\hline
\end{tabular}




\begin{tabular}{|l|l|l|l|l|l|l|}
\hline $\begin{array}{l}\text { Poor Organization of } \\
\text { Information Resources }\end{array}$ & 19 & 89 & 39 & 116 & 56 & 35 \\
\hline Defaced or Mutilated & 5 & 19 & 14 & 34 & 21 & 11 \\
\hline $\begin{array}{l}\text { Inadequate Reading } \\
\text { Facilities }\end{array}$ & 17 & 67 & 29 & 98 & 98 & 21 \\
\hline $\begin{array}{l}\text { Insufficient Electronics } \\
\text { Information Resources }\end{array}$ & 28 & 94 & 43 & 120 & 106 & 54 \\
\hline Insufficient Computers & 28 & 109 & 40 & 140 & 97 & 79 \\
\hline Poor Internet Connectivity & 25 & 115 & 47 & 136 & 125 & 76 \\
\hline Unreliable Power Supply & 30 & 125 & 47 & 151 & 179 & 87 \\
\hline
\end{tabular}

The study revealed through frequency distribution as can be seen in Table above that the respondents face a lot of challenges when seeking agricultural information in the libraries studied. These problems vary such as unreliable power supply which was

\section{Conclusion and Recommendations}

The conclusion of the research are based on the findings of the study, that the users in libraries studied uses both print and electronic information resources, that the users of libraries studied were satisfied with relevancy, content and accuracy of information resources. But the users were not satisfied with organization of prominent in all institute studied as indicated by the frequency. Power supply has been described by many researchers as one of the major problem that has been hindering development in Nigeria. Poor internet connectivity, insufficient computers,

information resources, accessibility to print and electronic resources, and means of awareness. Among the challenges the users face in the libraries studied are unreliable power supply, poor Internet Connectivity, insufficient computers, insufficient electronics information resources, insufficient means of awareness, inadequate 
current

information

resources,

Based on the findings of the study, the following recommendations were made:

1. The use of modern tools to get organized information resources

2. Provision of more up-to-date printed information resources.

\section{References}

Chavez, J., Espinoza, L., Mullane, M., Fiske, K., \& Lochhart, B. (2005). Library User Survey: Resources, Facilities and Circulation Service. Report on survey results. Retrieved from

http://www.paradisevalley.edu/library/ assessment/LibraryUserSurvey .

Checkland, P. \& Holwell, S. (2008).

Information, Systems and

Information Systems - making sense of the field. Chichester: Wiley \& Sons Ltd.

Cronin, J. J. \& Taylor, S. A. (1992). Measuring service quality: A reexamination and extension. Journal of Marketing. Vol. 56(6), pp 55-68.

Dulle, F.W. 2001. 'Researchers' perspectives on agricultural libraries as information sources in Tanzania." Library Review, 50:4:187-192.

Hanif, U. Zabed A. S. \&Nasir, U.M. (1997). Adequacy of reading resources and the satisfaction of the information needs of the faculty members: a case study of the Dhaka University Library. inaccessibility of agricultural information.

3. Improved internet connectivity for regular update e-resources in the library.

4. Provision of constant power supply in the libraries.

Retrieved April 10, 2009, from: http://infosciencetoday.org.

Iwhiwhu, B.E. \& Okorodudu, P.O. (2012). Public library information resources, facilities, and services: User satisfaction with the Edo State Central Library, Benin City, Nigeria. Library Philosophy and Practice. Retrieved from http://www.webpages.uidaho.edu/ m bolin/iwhiwhu-okorodudu.htm

Johnson, M.D. \& Fornell, C. (1991). A framework for comparing customer satisfaction across individuals and product categories, Journal of Economic Psychology, Vol. 12(2), pp 267-286.

Koovakki, D. \& Jalaja, V. (2005), "Satisfaction of the Career Seekers in the Resources and Services of Libraries in Kerala", ILA Bulletin, Vol. 41, No. 1, PP. 26-30.

Liu, R. \& Allmang, N. (2008)Assessing Customer Satisfaction at the NIST Research Library: Essential Tool for Future Planning. Issues in Science and Technology Librarianship. 
Retrieved from

http://www.library.ucsb.edu/istl/08summer/article3.html

Mugwisi, Ocholla and Mostert (2013) Access and use of libraries and information centers by agricultural researchers and extension workers in Zimbabwe.

http://creativecommons.org/licenses/ by $/ 3.0 /$

Naeem, H., \& Saif, I. (2009). Zone of tolerance for banks: a diagnostic model of service quality, The Service Industries Journal, 29(11), pp. 15471564.

Ntui, A. I. \& Orim, F. S. (2014) A

Comparative Study of Users'

Attitude Towards the Utilization

of LibraryServices in Cross River

University of Technology and

University of CalabarAvailable

Retrieved from

http://www.journalcra.com

International Journal Of Current

Research 6(12)11114-11117

Owusu-Acheaw, M. \& Larson, A.G. (2014).

Effective Use of Library Resources:

A Case Study of Business Students of Koforidua Polytechnic, Ghana. Information and Knowledge

Management.4, (12), 221-228.

Retrieved

From

http://www.iiste.org

Uganneya, S.A \& Idachaba, J.A (2005). Information System Effectiveness: A User's Satisfaction Approach Study of Francis Sulemanu (F. S.) Idachaba Library, University of Agriculture, Makurdi, Benue State, Nigeria", International Library Movement, 27(3) pp 165-172. 